\title{
The Enrichment Mechanism of REE at Sulfate and Methane Transition Zone (SMTZ) of the Northern Part of the South China Sea
}

\author{
Xie Rui, ${ }^{1,2,3,4}$ Wu Daidai $\left(\mathbb{D},{ }^{3}\right.$ Wei Jiangong $\left(\mathbb{D},{ }^{1,2,4}\right.$ Wang Liaoliang, ${ }^{1,2,4}$ Liu Lihua, ${ }^{3}$ \\ Li Wenjing, ${ }^{1,2,4}$ Wu Gang, ${ }^{1,2,4}$ and Guo Xudong ${ }^{1,2,4}$ \\ ${ }^{1}$ Southern Marine Science and Engineering Guangdong Laboratory (Guangzhou), Guangzhou 511458, China \\ ${ }^{2}$ MLR Key Laboratory of Marine Mineral Resources, Guangzhou Marine Geological Survey, Guangzhou 510075, China \\ ${ }^{3}$ Key Laboratory of Gas Hydrate, Guangzhou Institute of Energy Conversion, Chinese Academy of Sciences, \\ Guangzhou 510640, China \\ ${ }^{4}$ Academy of South China Sea Geological Science, China Geological Survey, Sanya 572025, China
}

Correspondence should be addressed to Wu Daidai; wudd@ms.giec.ac.cn and Wei Jiangong; weijiangong007@163.com

Received 23 May 2021; Revised 14 October 2021; Accepted 19 December 2021; Published 24 February 2022

Academic Editor: Nicoló Colombani

Copyright (C) 2022 Xie Rui et al. This is an open access article distributed under the Creative Commons Attribution License, which permits unrestricted use, distribution, and reproduction in any medium, provided the original work is properly cited.

Rare earth elements (REE) are important raw materials for electronic products and green-energy technology and deep-sea sediment as an important potential source of REE mineral. It is of great scientific significance to understand the influence of REE in deep-sea sediments. In this paper, thirty sediments samples and eleven sediments samples were collected at the site SH3 and SH1 of Shenhu area, respectively. The trace elements, major elements, and different Fe-Mn minerals were analyzed to investigate the role of anaerobic oxidation of methane (AOM) in the enrichment of rare earth elements in the marine sediments. The result showed that the content of $\sum \mathrm{REE} / \mathrm{Ti}$ increased at the top of sulfate and methane transition zone (SMTZ) at site $\mathrm{SH} 1$ and $\mathrm{SH} 3$. Combined with the analysis of different forms of ferromanganese minerals and the REE patterns, it is inferred that there is little influence of terrigenous input to the REE content. In contrary, the REE-rich carbonate phase and REE-rich Fe-Mn oxides (hydroxides) phase have important contribution of REE enrichment at the top of SMTZ. Meanwhile, the calculations of the quantitative relationship between the REE-rich carbonate phase and REE-rich Fe-Mn oxides (hydroxides) phase also confirm this conclusion. And the AOM caused the decrease of the REE-rich Fe-Mn oxides (hydroxides) phase and increase of the REE-rich carbonate phase. This is the potential explanation of $\sum$ REE/Ti enrichment at the top of SMTZ. This study is of great scientific significance for the study of REE enrichment mechanism in the methane seeps and provided a new sight of REE enrichment mechanism in deep-sea sediments.

\section{Introduction}

Anaerobic oxidation of methane $(\mathrm{AOM})$ is a very important biogeochemical process in marine sediments. It is considered to be of significant impact on climate change, atmospheric evolution, and related element cycle [1-5]. During $\mathrm{AOM}$, the residual porewater sulfate was consumed at the sulfate-methane transition zone (SMTZ). Here, an upward flux of methane reacts with a descending flux of sulfate [6-10], which is mediated by the metabolisms of methaneoxidizing archaea (MOA) and sulfate-reducing bacteria
(SR) [3, 11-16]. During the AOM, the methane-driven authigenic carbonates (MDAC), pyrite, and other minerals are enriched at the sulfate and methane transition zone (SMTZ) [11, 17-20]. Of course, SMTZ was not static and moved with the accumulation of sediments and the continuous supply of methane from below (Xie et al., 2021). Therefore, the sediment profile appeared multistage carbonate, and pyrite increases with the depth. The anomalies of the content of pyrite can help identify the paleo-SMTZ. Previous researches have shown that metal oxides and hydroxides could be served as the electron acceptor during methane 
oxidation [15, 21-24]. In addition, seafloor observation at seeps revealed that chemical and physical parameters, such as fluid flux, temperature, thermal diffusivity, $\mathrm{pH}$, and alkalinity, are also changed at the SMTZ [25-27]. Numerous studies have also demonstrated the AOM plays an important role in the cycle of $\mathrm{P}, \mathrm{S}, \mathrm{Fe}, \mathrm{Ca}, \mathrm{Mg}, \mathrm{B}$, and $\mathrm{Cl}$ [28-31]. However, up to now, there is little research about the influence of AOM on REEs.

Kato et al. [32] suggested that the deep-sea sediments would be an important source of REEs in the future [32]. Therefore, it is particularly important to understand the REE enrichment mechanism and the influencing factors in marine sediments. At present, the REE patterns are often used in indicating the source, reconstructing the redox environment, and investigating the impact of climate change [33-36]. While carbonates formed in the oxygenated bottom water usually show a smooth seawater REE profile characterized by the enrichment of heavy REEs (HREEs) and positive $\mathrm{La}$ and negative Ce anomalies [37]. And Pol et al. [38] suggested that four lighter REEs $\left(\mathrm{LREE}_{\mathrm{S}}\right)$ supported the growth of acidophilic methanotroph in volcanic mud pots, however, the higher atomic weight REEs (HREEs) were less conducive to growth [38]. These conclusions confirmed that the methane-rich marine sediments influence the REE distribution. Keltjens et al. also showed that light REE (LREEs) are an important constitute of methanotrophs [39, 40]. Shiller et al. [40] found the depletion of LREEs at methane-rich sediments of Gulf of Mexico [40]. Bayon et al. [41] observed Nd in the methane enriched plums above the cold seeps on the Niger Delta margin [41]. Otosaka and Noriki [42] discussed the compositional variations among REEs in settling particles to elucidate the sources of the REEs ([42]; Xiong et al., 2012; [10]). Although the REE enrichment mechanism has been studied in some sea areas by predecessors, the REE enrichment mechanism in the methane seeps has been rarely studied. In general, the Fe-Mn oxyhydroxides are sensitive to the early diagenetic remobilization in marine sediments [15, $16,36,43]$, which can be used in understanding the REEs influenced by the early diagenetic processes. In this paper, we want to answer the question of the mechanism of REE enrichments at the methane seep sediments and reveal the relationship between the AOM and REE cycle.

\section{Geological Settings}

The South China Sea is the largest marginal sea in the Western Pacific Ocean, formed under the convergent plate boundary of the Eurasian plate, the India Australia plate, and the Pacific plate [44-46]. Large and medium-sized Cenozoic sedimentary basins were developed on the northern slope of the South China Sea. Since the late Pliocene, a large amount of terrigenous organic matter has been transported and deposited on the northern slope of the South China Sea, which results in rapid sediment deposition and provides favorable conditions for the formation of gas sources $[10,47]$. The studied sites $\mathrm{SH} 1$ and SH3 are distributed in the Shenhu area (Figure 1). The Shenhu area is located in the zhu II depression area of the Pearl River Mouth Basin on the northern slope of the South China
Sea. Influenced by the formation and evolution of the Cenozoic sedimentary basin in the Pearl River Estuary, a wide range of submarine canyons, central diapir belts, and various types of diapir structures were developed in the Shenhu area [48], which provide good channels for the migration of deep source fluids [49]. The deposition rate in the Shenhu area increased and the content of organic matter was high during the Neocene. Guangzhou Marine Geological Survey carried out five gas hydrate drilling expeditions in the Shenhu area [50]. Geochemical analysis of the sediments and pore water at several stations in the Shenhu area also indicated that methane enriched fluid is active in this area [51,52].

\section{Samples and Methods}

3.1. Sampling Locations and Sample Collection. The samples used in this study were obtained at the sites $\mathrm{SH} 1$ and $\mathrm{SH} 3$ by the Guangzhou Marine Geological Survey in the Shenhu area of the South China Sea (SCS) in 2007 (Su et al. 2015). Among them, SH3 is of particular interest because of its high gas hydrate saturation and thick hydrate-bearing sediments. The sediments at sites $\mathrm{SH} 1$ and $\mathrm{SH} 3$ are mainly silty clay. In this study, 31 samples were obtained from site $\mathrm{SH} 3$ at 0-25 mbsf, and 11 samples were collected from site SH1.

3.2. Separation of Different Forms of Fe-Mn Minerals. The following Fe-Mn minerals were separated from all collected samples a. $\mathrm{Fe}_{\text {carb }}$-carbonate iron, mainly siderite $\left(\mathrm{FeCO}_{3}\right)$ and iron dolomite $\left[\mathrm{Ca}\left(\mathrm{Fe}^{2+}, \mathrm{Mg}^{2+}, \mathrm{Mn}^{2+}\right)\left(\mathrm{CO}_{3}\right)_{2}\right] ; \mathrm{b}$. $\mathrm{Fe}_{\text {oxl }}$-easy to reduce (amorphous) iron (hydrogen) oxides; c. $\mathrm{Fe}_{\mathrm{ox} 2}$ reducible (crystalline) iron oxides, $\mathrm{Fe}_{\mathrm{mag}}$-magnetite; d. $\mathrm{Fe}_{\mathrm{mag}}$-iron contained in magnetite $\left(\mathrm{Fe}_{3} \mathrm{O}_{4}\right)$.

The separation of said Fe-Mn minerals was carried out by the following procedure:

(1) Accurately weigh $0.25 \mathrm{~g}$ of dry sediment in a $50 \mathrm{~mL}$ clean centrifuge tube, drop $25 \mathrm{~mL}$ of $1 \mathrm{~mol} \cdot \mathrm{L}-1$ NaAc-HAc buffer $(\mathrm{pH}=4.5)$ into it, and place it after sealing. Shake on a shaker for 24 hours, adjust the speed to ensure that the sediment is suspended in the solution. After shaking, centrifuge at 4,000 rpm for 15 minutes, pass the supernatant through a $0.4 \mu \mathrm{m}$ filter membrane, and put the filtrate into a clean and dry centrifuge tube, $4^{\circ} \mathrm{C}$ cold storage is used to determine $\mathrm{Fe}_{\text {carb }}$ content

(2) Add $25 \mathrm{~mL} \mathrm{HONH}_{3} \mathrm{Cl}$ solution with a concentration of $50 \mathrm{~g} \cdot \mathrm{L}^{-1}$ dropwise to the solid residue in (1), seal it with a parafilm, put it in a shaker and shake for $2 \mathrm{~h}$, then put it in a centrifuge and centrifuge at $4000 \mathrm{rpm}$ $15 \mathrm{~min}$, pass the supernatant through a $0.4 \mu \mathrm{m}$ filter membrane, put the filtrate into a compiled centrifuge, and store it in a refrigerator at $4^{\circ} \mathrm{C}$ for determination of Feoxl content in the sediment

(3) Add $25 \mathrm{~mL}$ of $50 \mathrm{~g} \cdot \mathrm{L}-1 \mathrm{Na}_{2} \mathrm{~S}_{2} \mathrm{O}_{4}$ solution dropwise to the residual sediment in (2), seal and shake for 2 hours, centrifuge at $4000 \mathrm{rpm}$ for 15 minutes, and filter the supernatant through $0.4 \mu \mathrm{m}$ membrane, 


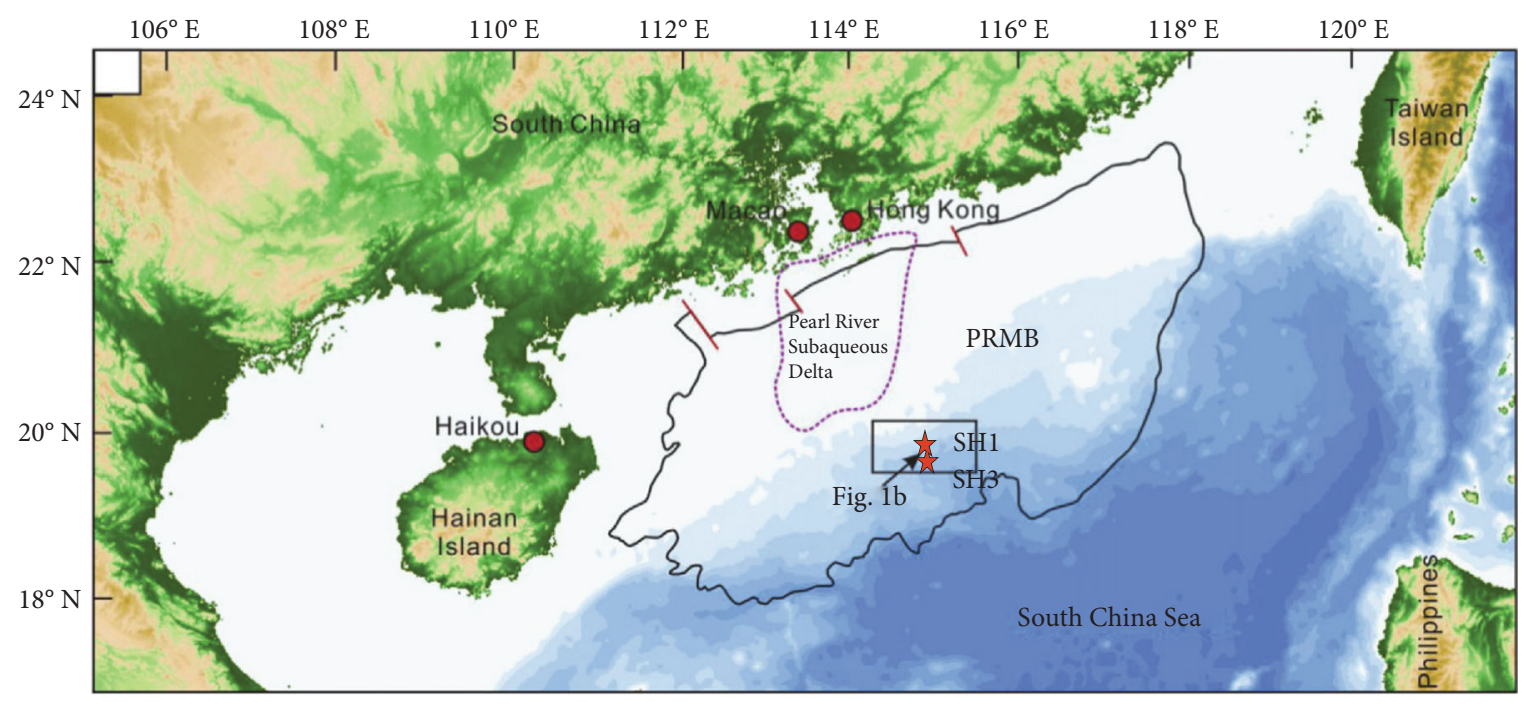

FIgure 1: The location of the study site SH1 and site SH3.

and filtrate is stored in a refrigerator at $4^{\circ} \mathrm{C}$ for determining $\mathrm{Fe}_{\text {oxl }}$ content

(4) Add $25 \mathrm{~mL}$ of $0.2 \mathrm{~mol} \cdot \mathrm{L}-1\left(\mathrm{NH}_{4}\right)_{2} \mathrm{C}_{2} \mathrm{O}_{4}$ dropwise to the residual sediment in (3), seal and shake for 6 hours, centrifuge at $4000 \mathrm{rpm}$ for $15 \mathrm{~min}$, and pass the supernatant through $0.4 \mu \mathrm{m}$ membrane, the filtrate is stored in a refrigerator at $4^{\circ} \mathrm{C}$ for determination of $\mathrm{Fe}_{\text {mag }}$ content

3.3. The Calculation Methods of $\delta C e$ and $\delta E u$. $\delta \mathrm{Ce}$ and $\delta \mathrm{Eu}$ anomalies were calculated from the relationships.

$\delta \mathrm{Ce}=\mathrm{Ce}_{\mathrm{N}} /\left(\mathrm{La}_{\mathrm{N}} \times \mathrm{Pr}_{\mathrm{N}}\right)^{1 / 2}$.

$\delta \mathrm{Eu}=\mathrm{Eu}_{\mathrm{N}} /\left(\mathrm{Sm}_{\mathrm{N}} \times \mathrm{Gd}_{\mathrm{N}}\right)^{1 / 2}$,

where $N$ represents chondrite normalization (data from Taylor and McClennan, 1985).

3.4. Major and Rare Earth Element Analysis of Bulk Sediments. In all samples, the major elements were determined at the Analytical and Testing Center of the Guangzhou Institute of Energy Conversion, Chinese Academy of Sciences. A Thermo ARL ADVANTta IntelliPower TM 2000 X-ray diffraction spectrometry (XRF) instrument was used to determine the contents of the major elements ( $\mathrm{Fe}$, $\mathrm{Mn}$, and Ti) in sediments. Measured XRF spectral data were converted to elemental and oxide contents by UniQuant semiquantitative analysis software.

The contents of rare earth elements in the whole rock were analyzed by inductively coupled plasma mass spectrometry (ICP-MS) on an Agilent 7700e instrument at the Wuhan Shangpu Analysis Technology Co., Ltd. And rare earth element analysis was carried out by the following procedure:

(1) The $74 \mu \mathrm{m}$ sample was placed in an oven at $105^{\circ} \mathrm{C}$ for $12 \mathrm{~h}$; (2) $50 \mathrm{mg}$ of the powder sample was weighed in a Teflon bomb; (3) $1 \mathrm{~mL}$ of high-purity nitric acid followed by $1 \mathrm{~mL}$ high-purity hydrofluoric acid was added to the sample; (4) the Teflon sample bomb was put into the steel sleeve, tightened, and placed in an oven at $190^{\circ} \mathrm{C}$ for more than $24 \mathrm{~h}$; (5) the sample bomb was cooled and place on a $140^{\circ} \mathrm{C}$ hotplate after opening the lid, the mixture was evaporated, and $1 \mathrm{~mL}$ of $\mathrm{HNO}_{3}$ was added prior to conducting another evaporative step (to a liquid free state); (6) $1 \mathrm{~mL}$ of high-purity nitric acid, $1 \mathrm{~mL}$ of Milli-Q water, and $1 \mathrm{~mL}$ of the internal standard (concentration, 1 ppm) were then added, and the Teflon bomb material was dissolved again, after which the bomb was placed into a steel jacket, tightened, and placed in an oven at $190^{\circ} \mathrm{C}$ for more than $12 \mathrm{~h}$; (7) lastly, the solution was transferred to a polyethylene bottle and diluted to $100 \mathrm{~g}$ with $2 \% \mathrm{HNO}_{3}$ for ICP-MS testing

\section{Result}

4.1. The Data of Rare Earth Elements at Site SH1 and Site SH3. All data of rare earth elements at site $\mathrm{SH} 1$ and site $\mathrm{SH} 3$ are listed in Table 1, the $\sum$ REE at site $\mathrm{SH} 1$ and site $\mathrm{SH} 3$ shows continuous fluctuation with the depth. There is no obvious anomaly, however, the $\sum \mathrm{REE} / \mathrm{Ti}$ (Table 1) displays abrupt increase of at $25 \mathrm{mbsf}$ of site $\mathrm{SH} 1$ and the $\sum \mathrm{REE} / \mathrm{Ti}$ represents an abrupt increase of at $16 \mathrm{mbsf}$ of site $\mathrm{SH}$. The content of $\mathrm{Al}$ and $\mathrm{Fe}$ shows the same tendency of varied $\sum \mathrm{REE} / \mathrm{Ti}$. The UCC-normalized patterns of site SH1 and Site SH3 show LREE and HREE deficits and MREE enrichment.

4.2. The Date of Fe-Mn Oxides (Hydroxides) and Fe-Mn Carbonate at Site SH3. All Fe-Mn oxides (hydroxides) and Fe-Mn carbonate are listed in Table 2. At site SH3, the concentration of $\mathrm{Fe}$ (oxl) and $\mathrm{Mn}$ (oxl) decreased at SMTZ (Figure 2). The concentration of Mn (carb) increased and the concentration of Fe (carb) slight increase at the SMTZ (Table 2). What is more, the content of REE has a positive correlation with the change of Fe-Mn oxides (hydroxides) and Fe-Mn carbonate phase. 


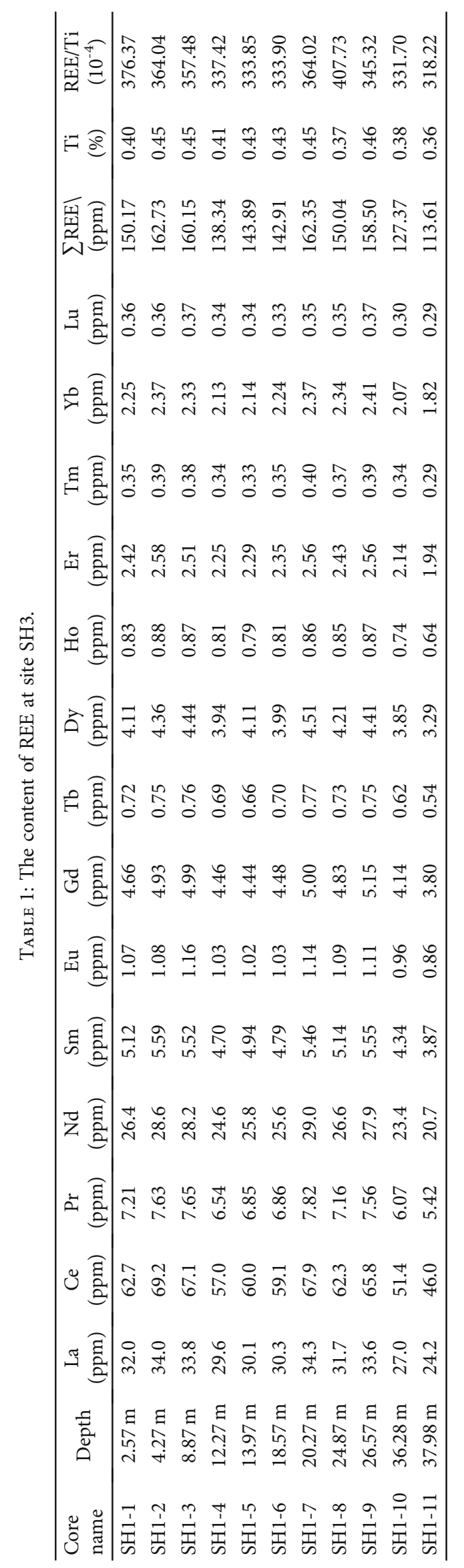


TABle 2: The content of different forms of Fe-Mn at site SH3.

\begin{tabular}{|c|c|c|c|c|c|}
\hline Core name & Depth (m) & $\mathrm{Fe}(\mathrm{crab})(\mathrm{ppm})$ & $\operatorname{Mn}(\mathrm{crab})(\mathrm{ppm})$ & $\mathrm{Fe}(\mathrm{oxl})(\mathrm{ppm})$ & $\operatorname{Mn}(\mathrm{oxl})(\mathrm{ppm})$ \\
\hline \multirow{19}{*}{ SH3 } & 0.87 & 3.693 & 1.547 & 1 & 1 \\
\hline & 1.68 & 4.13 & 1.605 & 10.64 & 0.061 \\
\hline & 2.57 & 0.521 & 1.242 & 10.34 & 0.057 \\
\hline & 4.27 & 2.459 & 1.048 & 10.23 & 0.083 \\
\hline & 5.93 & 4.171 & 0.968 & 3.75 & 0.037 \\
\hline & 6.22 & 0.626 & 0.714 & 3.448 & 0.186 \\
\hline & 9.68 & 0.663 & 0.933 & 3.598 & 0.182 \\
\hline & 10.57 & 1.109 & 0.858 & 8.635 & 0.083 \\
\hline & 11.42 & 7.789 & 1.024 & 8.924 & 0.075 \\
\hline & 13.12 & 1.089 & 0.981 & 9.024 & 0.063 \\
\hline & 14.82 & 5.663 & 1.132 & 5.82 & 0.016 \\
\hline & 16.85 & 1.124 & 1.00 & 12.01 & 0.085 \\
\hline & 17.68 & 0.877 & 1.016 & 15.13 & 0.109 \\
\hline & 18.57 & 0.364 & 0.896 & 13.42 & 0.115 \\
\hline & 19.42 & 0.726 & 1.241 & 11.29 & 0.125 \\
\hline & 20.27 & 1.581 & 1.467 & 10.76 & 0.129 \\
\hline & 21.08 & 1.194 & 1.034 & 10.64 & 0.061 \\
\hline & 21.93 & 0.711 & 1.089 & 5.581 & 0.028 \\
\hline & 22.82 & 0.902 & 1.038 & 7.68 & 0.096 \\
\hline
\end{tabular}

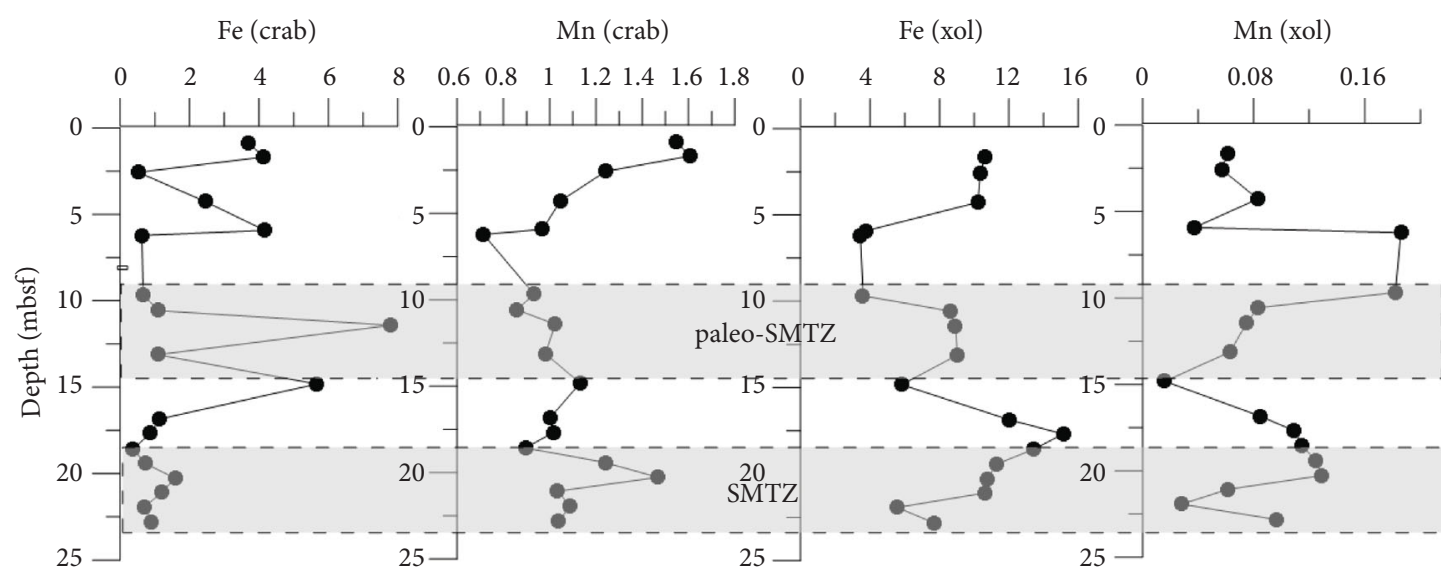

Figure 2: The Fe (crab), Mn (crab), Fe (oxl), and Mn (oxl) change with the depth at site SH3. The gray area is the AOM action area.

\section{Discussion}

5.1. The Influence Factors on the Source and Composition of REE. REEs are usually used to identify the sediment sources and help to reconstruct the bottom-water redox conditions $[28,53-55]$. At present, the contents of REEs in marine sediments are often influenced by the input of terrigenous sediments, the removal of REEs from the water column by authigenic minerals, and diagenetic alteration [56, 57]. Previous studies have also demonstrated that the REE patterns show the same characteristics as the source characteristics, therefore, the REE patterns can be applied to understand the REE provenance. In the Shenhu area, the sediments are mainly from the Pearl River, SW Taiwan, Luzon Rivers, and some authigenic minerals [58, 59]. Beyond that, $\mathrm{Wu}$ et al. (2017) also proved that aeolian transport from land and volcanic ash accounts for less of Shenhu marine sediments $[15,60]$. Moreover, most sediments transported into the SCS by the Pearl River and Mekong River are deposited on the inner shelf and along the shore. In contrast, SW Taiwan rivers supply a large amount of sediments $\left(>70 \mathrm{Mt} \mathrm{yr}^{-1}\right.$ ) to the northern SCS through a deep-water bottom current along the $2000 \mathrm{~m}$ isobath.

In this paper, the upper continental crust- (UCC-) normalized REE patterns at sites $\mathrm{SH} 1$ and $\mathrm{SH} 3$ are characterized by slight light REE (LREE (La, Ce, Pr, and Nd)) and heavy REE (HREE (Ho, Er, Tm, Yb, and Lu)), and the enrichment of middle REE (MREE (Sm, Eu, Gd, Tb, and Dy)) (Figure 3). This MREE-bulge type pattern is a typical feature of anoxic pore water in the marine sediments [61], and the anoxic 

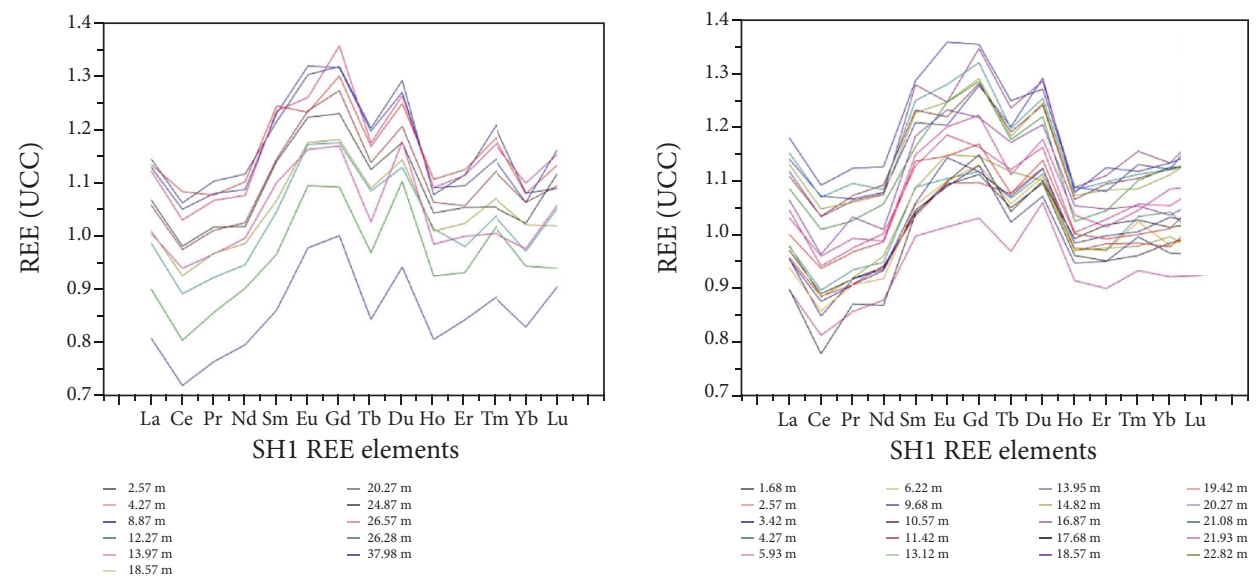

FIgURE 3: The UCC-normalized patterns of site SH1 and site SH3.

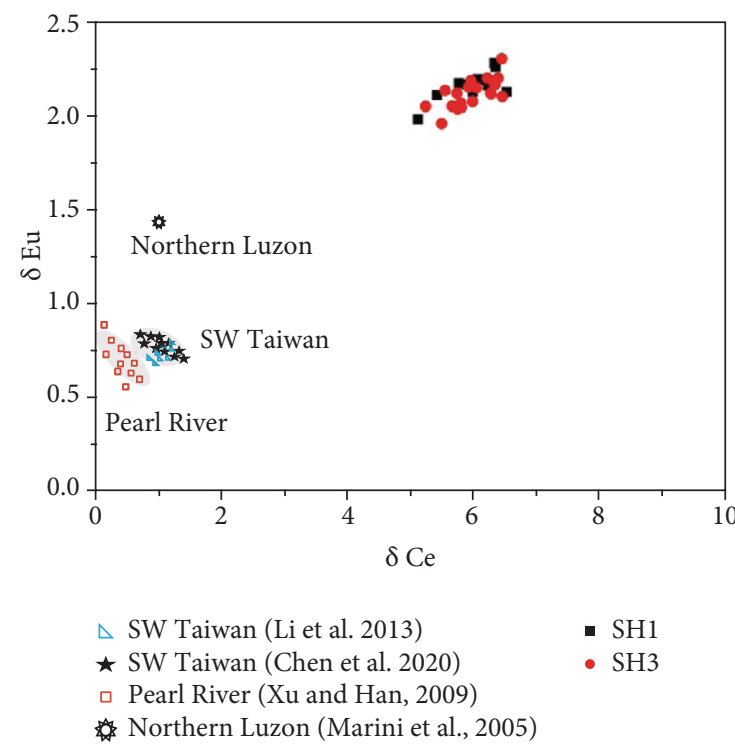

(a)

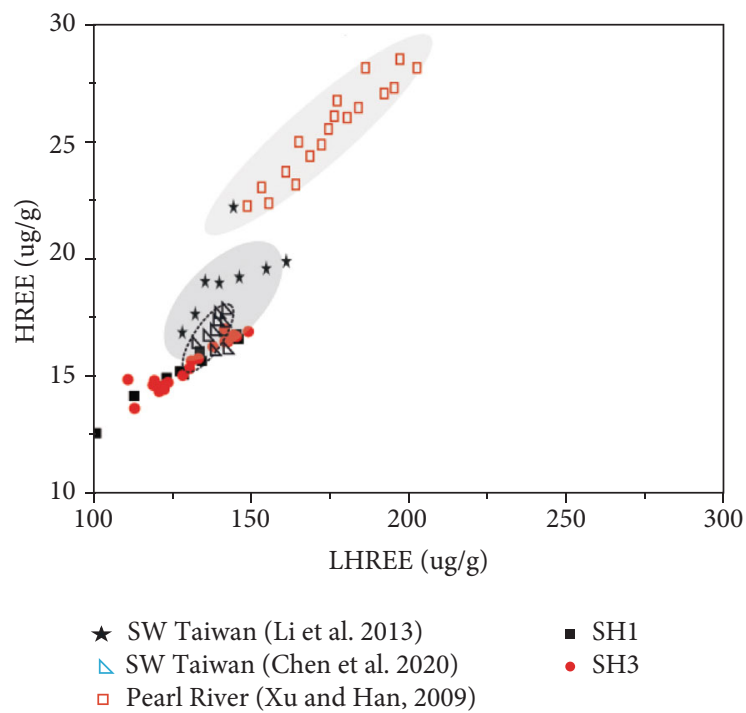

(b)

Figure 4: (a) The plot of $\delta$ Eu and $\delta$ Ce. (b) The plot of the HREE and LREE. Meanwhile, the distribution of the SW Taiwan referend from the (Li et al. 2013), Pearl river referend from the (Xu and Han, 2009), and the Luzhon river referend from (Marini et al. 2005).

environment is interpreted as the consequence of AOM, because, during the AOM process, oxygen will gradually consume $[62,63]$. Previous studies have demonstrated that Ce occurs as $\mathrm{Ce}^{3+}$ like other REE elements in anoxic conditions, whereas under oxic conditions, the soluble $\mathrm{Ce}^{3+}$ is oxidized to insoluble $\mathrm{Ce}^{4+}[64,65]$. In the studied area, all the samples at sites $\mathrm{SH} 1$ and $\mathrm{SH} 3$ showed weak negative $\mathrm{Ce}$ anomalies, indicating a reduced environment (Figure 3). And this conclusion is consistent with the previous result. Furthermore, sites SH1 and SH3 show lower content of HREE and LREE compared with those of the SW Taiwan, Luzou Rivers, and Parel Rivers. The result suggests that the REE receives less influence of the input of Pearl River, SW Taiwan, and Luzhon Rivers (Figure $4(\mathrm{~b})$ ). $\mathrm{Ce}^{3+}$ is oxidized to $\mathrm{Ce}^{4+}$ under oxidizing conditions, resulting in a negative Ce anomaly, which therefore is an effective indicator of oxic conditions, and negative Ce anomalies in marine carbonates have been shown to reflect seawater oxygenation. At site $\mathrm{SH} 1$ and $\mathrm{SH} 3$, the $\delta \mathrm{Ce}$ and $\delta \mathrm{Eu}$ were obviously higher than the $\delta \mathrm{Ce}$ and $\delta \mathrm{Eu}$ of the Parel rivers, SW Taiwan, and Luzhon rivers (Figure 4(a)). Indicating an anoxic and methane seep sediment environment at site $\mathrm{SH} 1$ and $\mathrm{SH} 3$, such a sediment environment is very favorable for AOM. The conclusion is consistent with the previous study. Therefore, the contents of REE at sites SH1 and SH3 are mainly influenced by the authigenic minerals and later diagenesis induced by the AOM. Combined with the reduced environment, we believe that the REEs are mainly influenced by the authigenic minerals and diagenetic alteration rather than detrital minerals that usually contain much higher $\mathrm{REE}_{\mathrm{S}}$ [61]. However, the northern part of The South China Sea is a high incidence area of detrital input; to eliminate the impact of detrital 


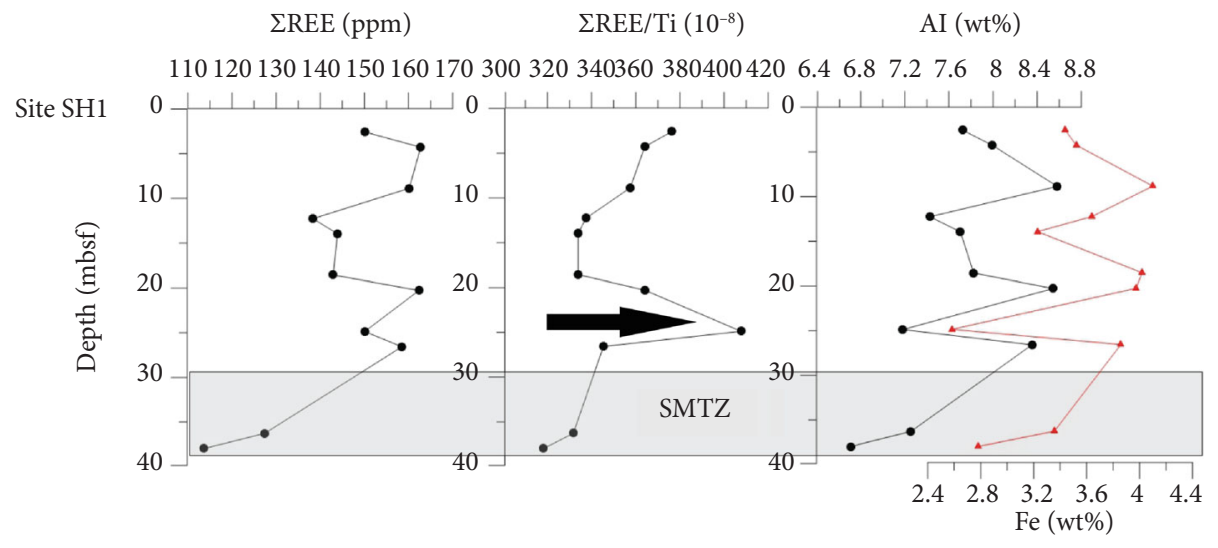

(a)

(b)

¿REE (ppm) $\begin{array}{lllllllllllllllll}120 & 130 & 140 & 150 & 160 & 170 & 300 & 320 & 340 & 360 & 380 & 6.8 & 7.2 & 7.6 & 8 & 8.4 & 8.8\end{array}$

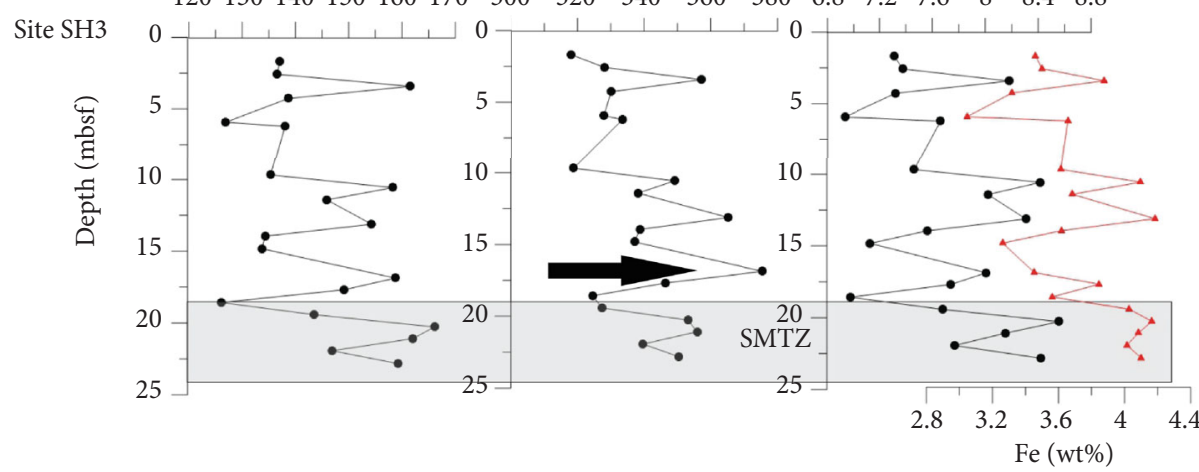

(d) (e)

Figure 5: The content of REE, REE/Ti, Al, and Fe change with the depth. The gray area is the current AOM action area. Among them, $\sum \mathrm{REE} / \mathrm{Ti}$ has a remarkable increase at the top of the SMTZ. The black arrow indicates the increased position of REEs.

input on REE, the REE/Ti ratios were used to eliminate the influence of terrigenous sediment input. At site SH1, the $\sum \mathrm{REE} / \mathrm{Ti}$ (Table 1) contents changed from $318 \mathrm{ug} / \mathrm{g}$ to $407 \mathrm{ug} / \mathrm{g}$ and show high values at $25 \mathrm{mbsf}$ with decreased content of Fe and Al. At site SH3, the $\sum \mathrm{REE} / \mathrm{Ti}$ contents varied from $318 \mathrm{ug} / \mathrm{g}$ to $375 \mathrm{ug} / \mathrm{g}$, and the highest value is at 17 mbsf with a slightly increase of $\mathrm{Fe}$ and $\mathrm{Al}$ (Figure 5). This characteristic indicates that the abrupt increase at $25 \mathrm{mbsf}$ of site $\mathrm{SH} 1$ and $17 \mathrm{mbsf}$ of site $\mathrm{SH} 3$ is not influenced by the input of terrigenous material. It is more likely to be influenced by the later diagenesis or effects of authigenic minerals.

5.2. The Influence of AOM on the Enrichment of REEs. REE content is usually increased with the sediment depth [66, 67]. However, the content of REEs does not increase with the depth at sites $\mathrm{SH} 1$ and $\mathrm{SH} 3$. As mentioned above, the $\sum \mathrm{REE} / \mathrm{Ti}$ increases abruptly at sites $\mathrm{SH} 1$ and $\mathrm{SH} 3$ at $25 \mathrm{mbsf}$ and $17 \mathrm{mbsf}$, respectively (Figure 5). However, the sulfate and methane transition zone (SMTZ) is at 27$36 \mathrm{msbf}$ of site SH1 and the SMTZ at $18-25 \mathrm{mbsf}$ of site SH3 $[15,16,24]$. The results show that the $\sum \mathrm{REE} / \mathrm{Ti}$ increased above the SMTZ. As the previous discussion, the REE is mainly influenced by the later diagenetic and authigenic minerals. Theoretically, REE should be enriched in SMTZ instead of above of SMTZ. Hence, the main question is to explain the enrichment of REE at the top of SMTZ. Akagi et al. [53] found that the content of REE contributed from the carbonate with a higher REE concentration at the North Pacific Ocean and Bering Sea [53]. Liao et al. [68] considered that biogenetic apatite is one of the most important REY carriers in REY-rich deep-sea sediment [68]. Kato et al. [32] also suggested that the main host of the REE is an Fe-hydroxide precipitate from hydrothermal plumes that have taken up rare earth elements from ambient seawater. No matter how the REE forms, as a major process of early diagenesis, AOM often results in the enrichment of authigenic minerals in marine sediments. Meanwhile, AOM also influences the metal oxides and the apatite [15], indicating that it is likely to affect the distribution of REE. To further investigate the relationship between AOM and the content of REE, the Fe-Mn oxides (hydroxides) and Fe-Mn carbonate phase at site $\mathrm{SH} 3$ were analyzed.

At site $\mathrm{SH} 3$, there is no correlation between the content of REE and the content of Fe-Mn oxides (hydroxides) at $0-6 \mathrm{mbsf}$. However, at the paleo-SMTZ $(8-15 \mathrm{mbsf})$ and current-SMTZ, it showed an obviously positive correlation (Figure 6). At the same time, the Fe-Mn carbonate phase also showed a positive correlation with the content of REE (Figure 6). This characteristic shows that the REEcarbonate phase and REE-metal oxides (hydroxides) have 

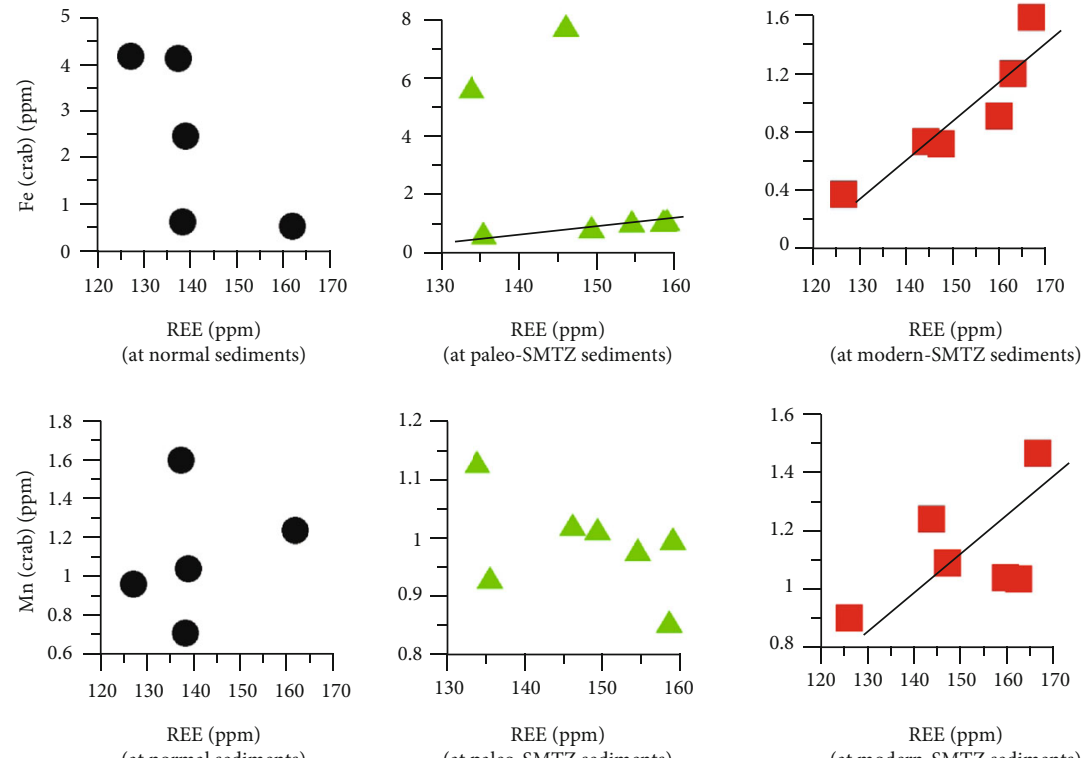

(at normal sediments)
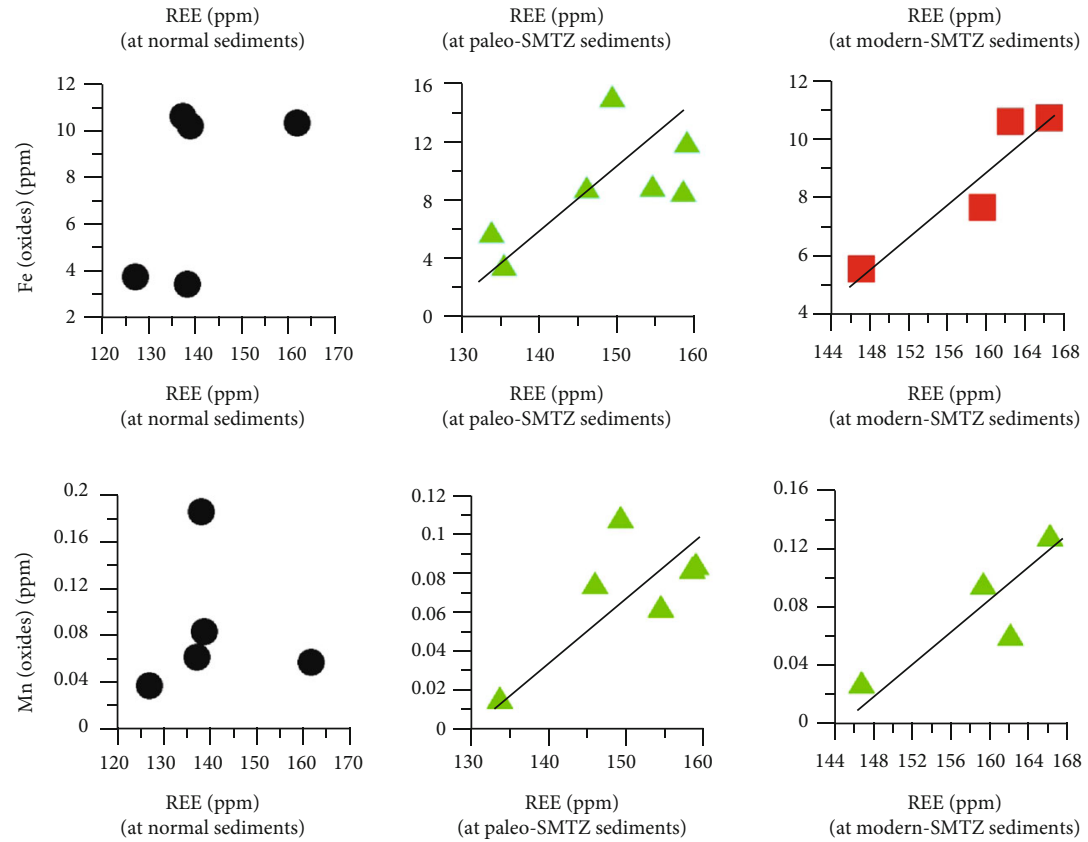

Figure 6: The correlation of REE and different forms metal oxides or carbonate presented at paleo-SMTZ sediments and modern-SMTZ sediments.

an important contribution to the content of REE at the top of SMTZ. To better comprehend the role of LREE and HREE in SMTZ, the relationship between HREE and Fe-Mn oxides (hydroxides) is also investigated (Figure 7). The result showed the HREE has a positive correlation with the authigenic mineral (Figure 7). Therefore, it is proved that the REE-rich Fe-Mn carbonate phase and REE-rich Fe-Mn oxides (hydroxides) affect the HREE. During the AOM, HS ${ }^{-}$ and $\mathrm{HCO}_{3}{ }^{-}$are generated, and the $\mathrm{HCO}_{3}^{-}$will react with the $\mathrm{Ca}^{2+}$ to form the carbonate. Therefore, it is often found the vast carbonate at methane seep areas. Meanwhile, HS $^{-}$is also produced by the AOM, which reductively dissolves iron oxides ( $\mathrm{FeOx}$ ), leading to the precipitation of Fe sulfides (e.g., greigite, mackinawite, and pyrite) (Riedinger et al., 2014). During the reductive of $\mathrm{Fe}_{\mathrm{ox}}$ dissolution, the $\mathrm{Fe}_{\mathrm{ox}}$-associated
REE is released to the ambient pore water and accumulates in different forms, such as the REE-rich carbonate phase.

5.3. Quantitative Calculation of Enrichment of REE. During the AOM, the Fe-Mn oxides (hydroxides) were reduced by the HS- and the content of authigenic minerals increased at SMTZ. The specific reaction is as follow:

$$
\begin{gathered}
\mathrm{CH}_{4}+\mathrm{SO}_{4}^{2-} \longrightarrow \mathrm{HCO}_{3}^{-}+\mathrm{HS}^{-}+\mathrm{H}_{2} \mathrm{O} \\
2 \mathrm{HCO}_{3}^{-}+\mathrm{Ca}^{2+}\left(\frac{\mathrm{Mg}^{2+}}{\mathrm{Sr}^{2+}}\right) \longrightarrow \mathrm{Ca}\left(\frac{\mathrm{Mg}}{\mathrm{Sr}}\right) \mathrm{CO}_{3}+\mathrm{CO}_{2}+\mathrm{H}_{2} \mathrm{O}
\end{gathered}
$$



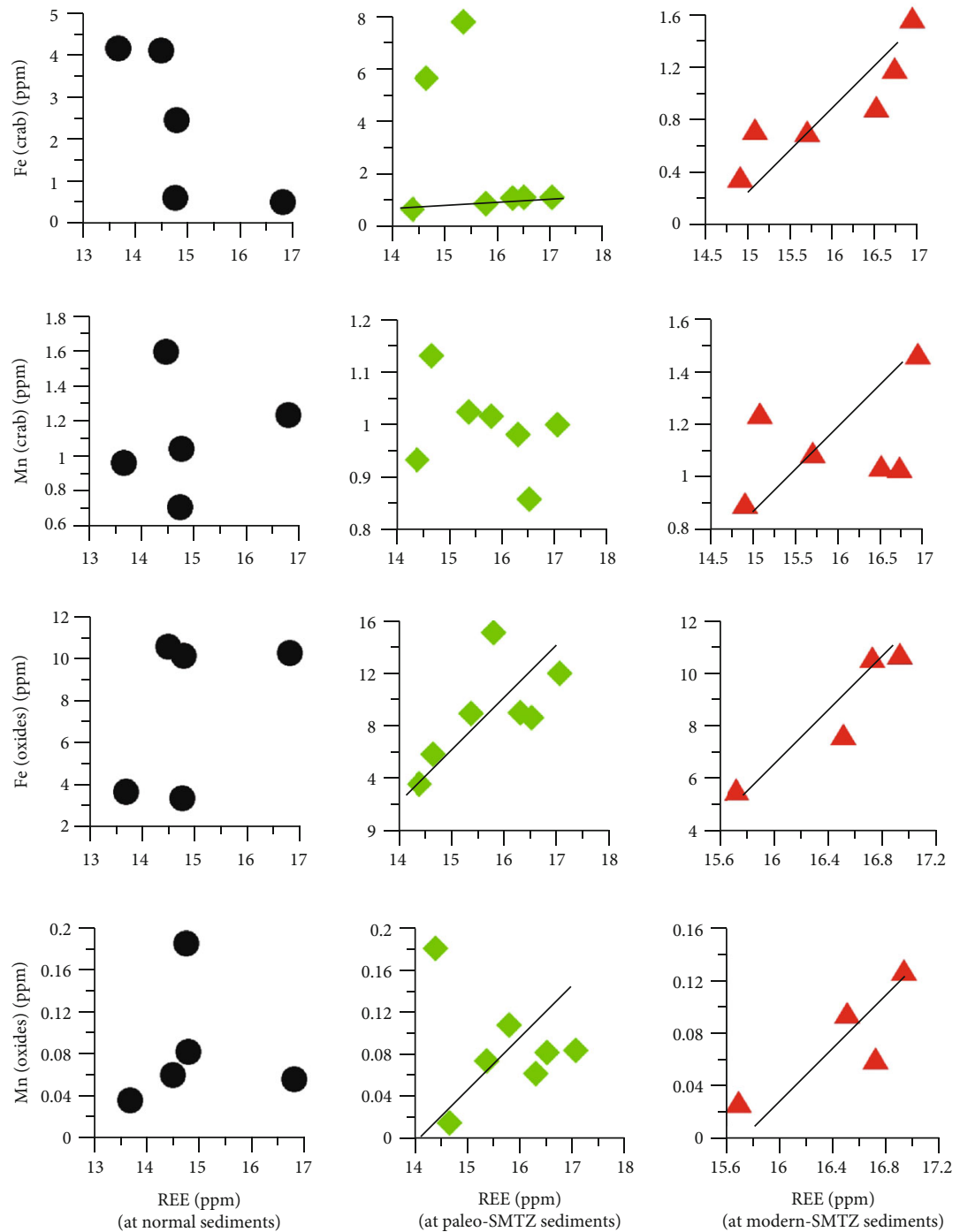

FIGURE 7: The correlation of HREE and different forms metal oxides or carbonate presented at paleo-SMTZ sediments or modern-SMTZ sediments.

$$
2 \mathrm{FeO}(\mathrm{OH})+\mathrm{H}_{2} \mathrm{~S}+4 \mathrm{H}^{+} \longrightarrow 2 \mathrm{Fe}^{2+}+\mathrm{S}^{0}+4 \mathrm{H}_{2} \mathrm{O}
$$

As can be seen from formulas (1), (2), and (3), when 1 mole of carbonate is produced, 4 moles of metal oxide are reduced.

$$
\frac{\mathrm{a}(\text { Carbonate phase })_{\text {increase }}}{\mathrm{a}(\mathrm{Fe}-\mathrm{Mn} \text { oxides }(\text { hydroxides }))_{\text {reduces }}}=\frac{1}{4} \text {. }
$$

[69] analyzed the different forms of REE in different sediments. And conclude that the content of REE in Fe-Mn oxides phase (hydroxides) is about 12.3 times than the content of REE in the carbonate phase.

$$
\frac{\mathrm{REE}-\text { rich carbonate pahse }}{\mathrm{Ree}-\text { rich Fe }- \text { Mn xoides (hydroxides) }}=\frac{1}{12.3} \text {. }
$$

According to formulas (4) and (5), it can be seen that the content of rare earth elements in the sediment will decrease by $50 \mathrm{ppm}$ when $1 \mathrm{~mol}$ carbonate is produced and 4 -mole Fe-Mn oxide reduction. The above discussion has confirmed that REE is primarily affected by the carbonate phase and Fe-Mn oxides (hydroxides). Therefore, the content of REE change should follow this quantitative relationship at SMTZ. At site SH1, the content of REE at $20 \mathrm{mbsf}$ is $162.35 \mathrm{ppm}$, and the content of REE at $37.98 \mathrm{mbsf}$ is about $113 \mathrm{ppm}$, the difference is about $49 \mathrm{ppm}$. The same quantitative relationship can also be found in site SH3. Therefore, the conclusion is consistent with the above.

5.4. The Enrichment Mechanism of REE Influenced by AOM. Previous studies have demonstrated that sulfate-driven anaerobic oxidation of methane (SD-AOM) can cause the enrichment of carbonate. At the same time, most of the metal oxides will convert to metal sulfide in the presence of excess hydrogen sulfide $[2,3,70]$. With the deepening of research, metal-driven anaerobic oxidation of methane (MD-AOM) is found at the bottom of the SMTZ worldwide [15, 24, 38, 71]. During the metal-driven anaerobic oxidation of methane 


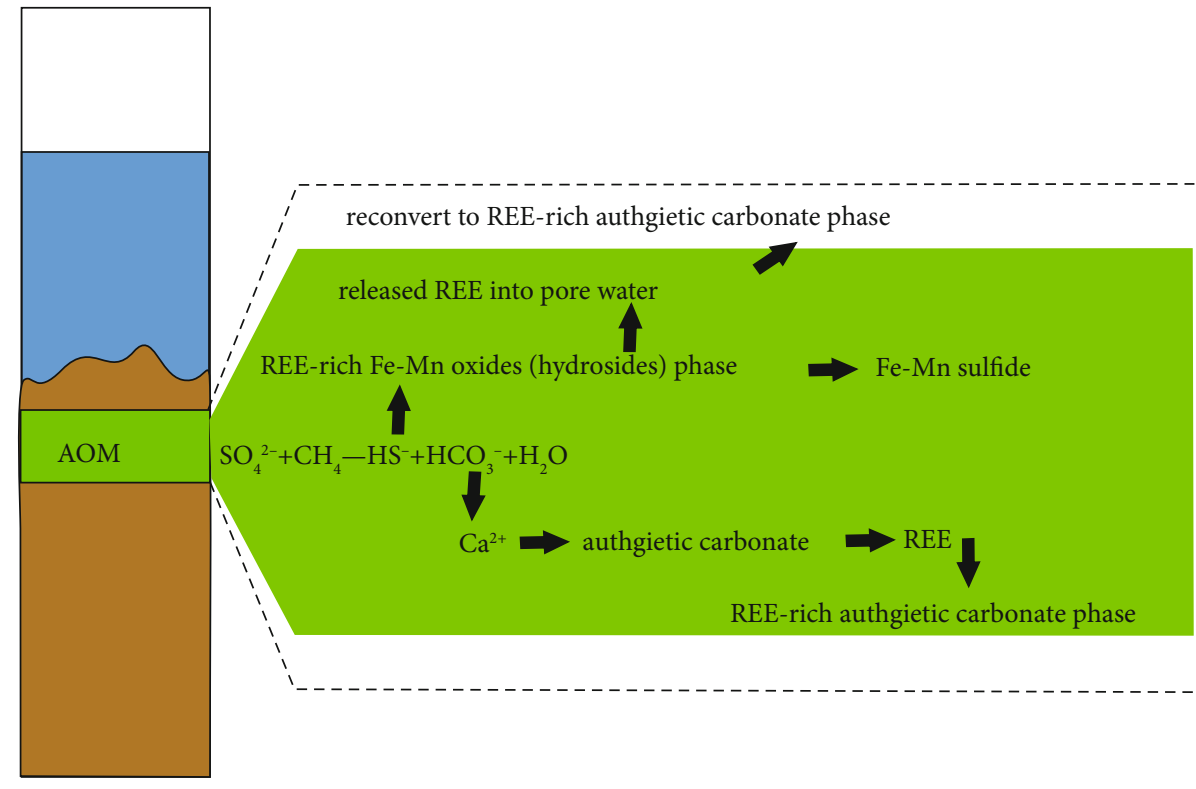

Figure 8: At first, it is inferred that the metal oxides (hydroxides) are reduced at the SMTZ, meanwhile, the REE-rich Fe-Mn oxides (hydroxides) will release REE in the pore water during the AOM. The released REE will reconvert to the REE-rich carbonate phase. At the SMTZ, the REE-rich Fe-Mn carbonate phase increased and the REE-rich Fe-Mn oxides (hydroxides) decreased. Therefore, the REE is not enriched in the SMTZ while enriched at the top of the SMTZ.

(MD-AOM), more metal oxides are converted to metal sulfides compared to the SD-AOM. The previous discussion suggested that the REE-rich carbonate phase and REE-rich Fe-Mn oxides (hydroxides) have an important contribution to the REE. The question is that why the REEs are not enriched at the SMTZ while enriched on top of the SMTZ. Based on our results, it is inferred that the metal oxides (hydroxides) are reduced at the SMTZ; meanwhile, the REE-rich Fe-Mn oxides (hydroxides) will release REE in the pore water during the AOM. The released REE will reconvert to the REE-rich carbonate phase. At the SMTZ, the REE-rich Fe-Mn carbonate phase increased and the REE-rich Fe-Mn oxides (hydroxides) decreased. Therefore, the REE is not enriched in the SMTZ while enriched at the top of the SMTZ (Figure 8). And this study revealed the influence of AOM on REE at methane seeps areas. It can help us to better understand the mechanism of REE in methane seep area.

\section{Conclusion}

In this paper, there is an obvious increase of $\sum \mathrm{REE} / \mathrm{Ti}$ at the top of SMTZ of sites SH1 and SH3. Based on the analysis of $\delta$ Eu vs. $\delta \mathrm{Ce}, \mathrm{HREE}$ vs. LREE, and the REE-UCC normalized patterns, the REE characteristics of $\mathrm{SH} 1$ and $\mathrm{SH} 3$ are different from the Pearl River, SW Taiwan, and the Luzhon river, indicating that the terrigenous sediment input has little contribution to the REE enrichments. Hence, the REE was suggested to be more influenced by the authigenic minerals and later diagenesis. Combined the analysis of the different forms of Fe-Mn oxides (hydroxides) minerals, carbonate phase, and the REE patterns, the Fe-Mn oxides (hydroxides) and Fe-Mn carbonate phase have a positive correlation with the REE content, indicating that the REE-rich carbonate phase and REE-rich Fe-Mn oxides (hydroxides) phase have the important contribution of REE enrichment at the SMTZ. However, there is little increase of REE at the SMTZ, it increased at the top of the SMTZ. It is inferred that the AOM results in the decrease of the REE-rich Fe-Mn oxides (hydroxides) phase and a decrease of the REE-rich carbonate phase. This is the reason why the $\sum \mathrm{REE} / \mathrm{Ti}$ is enriched at the top of the SMTZ. Our results are of great scientific significance for understanding the REE enrichment mechanism in the methane seeps.

\section{Data Availability}

All the data have been supplied in the article in the form of a table.

\section{Conflicts of Interest}

The authors declare that they have no conflicts of interest.

\section{Acknowledgments}

The authors thank the voyage scientists for their hard work in collecting the research samples. This research was partially supported by the Key Special Project for Introduced Talents Team of Southern Marine Science and Engineering Guangdong Laboratory (Guangzhou) (GML2019ZD0201), the Guangdong Basic and Applied Basic Research Fund Project (2021A1515011509), Municipal Science and Technology Program of Guangzhou (no. 201904010311), the Special project for marine economy development of Guangdong Province (no. GDME-2018D002), Institution of South China Sea Ecology and Environmental Engineering, Chinese Academy of Sciences (no. ISEE2018YB03), and the Youth Innovation Promotion Association CAS (no. 2014321). 


\section{References}

[1] G. Aloisi, C. Pierre, J. M. Rouchy, J. P. Foucher, and J. Woodside, "Methane-related authigenic carbonates of eastern Mediterranean Sea mud volcanoes and their possible relation to gas hydrate destabilisation," Earth and Planetary Science Letters, vol. 184, pp. 321-338, 2000.

[2] I. Bar-Or, M. Elvert, W. Eckert et al., "Iron-coupled anaerobic oxidation of methane performed by a mixed bacterial-archaeal community based on poorly reactive minerals," Environmental Science \& Technology, vol. 51, pp. 12293-12301, 2017.

[3] E. J. Beal, M. W. Claire, and C. H. House, "High rates of anaerobic methanotrophy at low sulfate concentrations with implications for past and present methane levels," Geobiology, vol. 9, pp. 131-139, 2011.

[4] E. J. Beal, C. H. House, and V. J. Orphan, "Manganese- and iron-dependent marine methane oxidation," Science, vol. 325, pp. 184-187, 2009.

[5] A. Boetius, K. Ravenschlag, C. J. Schubert et al., "A marine microbial consortium apparently mediating anaerobic oxidation of methane," Nature, vol. 407, pp. 623-626, 2000.

[6] F. Beulig, H. Røy, M. G. SE, and B. B. Jørgensen, "Cryptic CH4 cycling in the sulfate-methane transition of marine sediments apparently mediated by ANME-1 archaea," ISME Journal, vol. 13, pp. 250-262, 2019.

[7] C. Cai, A. O. Leu, G. J. Xie et al., "A methanotrophic archaeon couples anaerobic oxidation of methane to Fe (III) reduction," The ISME Journal, vol. 12, pp. 1929-1939, 2018.

[8] J. Chen, Z. Zhou, and J.-D. Gu, "Complex community of nitrite-dependent anaerobic methane oxidation bacteria in coastal sediments of the Mai Po wetland by PCR amplification of both 16S rRNA and pmoA genes," Applied Microbiology and Biotechnology, vol. 99, pp. 1463-1473, 2015.

[9] P. C. Chuang, A. W. Dale, K. Wallmann et al., "Relating sulfate and methane dynamics to geology: accretionary prism offshore SW Taiwan," Geochemistry Geophysics Geosystems, vol. 14, pp. 2523-2545, 2013.

[10] J. Wei, J. Liang, J. Lu, W. Zhang, and Y. He, "Characteristics and dynamics of gas hydrate systems in the northwestern South China Sea - results of the fifth gas hydrate drilling expedition," Marine and Petroleum Geology, vol. 110, pp. 287-298, 2019.

[11] C. Akhoudas, N. Chevalier, M. M. Blanc-Valleron et al., "Methane-derived stromatolitic carbonate crust from an active fluid seepage in the western basin of the sea of Marmara: mineralogical, isotopic and molecular geochemical characterization," Deep Sea Research Part II: Topical Studies in Oceanography, vol. 153, pp. 110-120, 2018.

[12] G. Aloisi, I. Bouloubassi, S. K. Heijs et al., "CH4-consuming microorganisms and the formation of carbonate crusts at cold seeps," Earth and Planetary Science Letters, vol. 203, pp. 195203, 2002.

[13] D. Feng, J. W. Qiu, Y. Hu et al., "Cold seep systems in the South China Sea: an overview," Journal of Asian Earth Sciences, vol. 168, pp. 3-16, 2018.

[14] H. Guan, D. Birgel, J. Peckmann et al., "Lipid biomarker patterns of authigenic carbonates reveal fluid composition and seepage intensity at Haima cold seeps, South China Sea," Journal of Asian Earth Sciences, vol. 168, pp. 163-172, 2018.

[15] D. Wu, R. Xie, J. Liu et al., "Zone of metal-driven anaerobic oxidation of methane is an important sink for phosphorus in the Taixinan Basin, South China Sea," Marine Geology, vol. 427, article 106268, 2020.

[16] R. Xie, D. Wu, J. Liu, T. Sun, L. Liu, and N. Wu, "Evolution of gas hydrates inventory and anaerobic oxidation of methane (AOM) after 40ka in the Taixinan Basin, South China Sea," Deep Sea Research Part I: Oceanographic Research Papers, vol. 152, article 103084, 2019.

[17] C. Canet, R. M. Prol-Ledesma, J. C. Melgarejo, and A. Reyes, "Methane-related carbonates formed at submarine hydrothermal springs: a new setting for microbially-derived carbonates?," Marine Geology, vol. 199, pp. 245-261, 2003.

[18] B. Cavalazzi, R. Barbieri, S. L. Cady et al., "Iron-framboids in the hydrocarbon-related middle Devonian Hollard mound of the anti-atlas mountain range in Morocco: evidence of potential microbial biosignatures," Sedimentary Geology, vol. 263-264, pp. 183-193, 2012.

[19] A. Crémière, A. Lepland, S. Chand et al., "Fluid source and methane-related diagenetic processes recorded in cold seep carbonates from the Alvheim channel, Central North Sea," Chemical Geology, vol. 432, pp. 16-33, 2016.

[20] Z. Dolníček, T. Lehotský, M. Slobodník, E. Hejtmánková, A. Grígelová, and J. Zapletal, "Mineral-forming and diagenetic processes related to tertiary hydrocarbon seepage at the bohemian Massif/outer Western Carpathians interface: evidence from the Hrabůvka quarry, Moravia, Czech Republic," Marine and Petroleum Geology, vol. 52, pp. 77-92, 2014.

[21] T. Baumberger, R. W. Embley, S. G. Merle, M. D. Lilley, N. A. Raineault, and J. E. Lupton, "Mantle-derived helium and multiple methane sources in gas bubbles of cold seeps along the Cascadia continental margin," Geochemistry, Geophysics, Geosystems, vol. 19, pp. 4476-4486, 2018.

[22] Y. Hu, D. Feng, J. Peckmann, H. H. Roberts, and D. Chen, "New insights into cerium anomalies and mechanisms of trace metal enrichment in authigenic carbonate from hydrocarbon seeps," Chemical Geology, vol. 381, pp. 55-66, 2014.

[23] X. Wang, C. Li, and L. Zhou, "Metal concentrations in the mussel Bathymodiolus platifrons from a cold seep in the South China Sea," Deep Sea Research Part I: Oceanographic Research Papers, vol. 129, pp. 80-88, 2017.

[24] R. Xie, D. Wu, J. Liu, T. Sun, L. Liu, and N. Wu, "Geochemical evidence of metal-driven anaerobic oxidation of methane in the Shenhu Area, the South China Sea," International Journal of Environmental Research and Public Health, vol. 16, p. 3559, 2019.

[25] B. Carson, M. Kastner, D. Bartlett, J. Jaeger, H. Jannasch, and Y. Weinstein, "Implications of carbon flux from the Cascadia accretionary prism: results from long-term, in situ measurements at ODP site 892B," Marine Geology, vol. 198, pp. 159180, 2003.

[26] I. Macdonald, L. Bender, M. Vardaro, B. Bernard, and J. Brooks, "Thermal and visual time-series at a seafloor gas hydrate deposit on the Gulf of Mexico slope," Earth and Planetary Science Letters, vol. 233, no. 1-2, pp. 45-59, 2005.

[27] M. F. Vardaro, M. D. IR, L. C. Bender, and N. L. Guinasso, "Dynamic processes observed at a gas hydrate outcropping on the continental slope of the Gulf of Mexico," Geo-Marine Letters, vol. 26, pp. 6-15, 2006.

[28] D. Birgel, D. Feng, H. H. Roberts, and J. Peckmann, "Changing redox conditions at cold seeps as revealed by authigenic carbonates from Alaminos canyon, northern Gulf of Mexico," Chemical Geology, vol. 285, pp. 82-96, 2011. 
[29] D. Lim, J. Choi, Z. Xu et al., "Methane-derived authigenic carbonates from the Ulleung basin sediments, East Sea of Korea," Continental Shelf Research, vol. 29, no. 13, pp. 1588-1596, 2009.

[30] S. Lin, W.-C. Hsieh, Y. C. Lim, T. F. Yang, C.-S. Liu, and Y. Wang, "Methane migration and its influence on sulfate reduction in the good weather ridge region, South China Sea continental margin sediments," Terrestrial Atmospheric and Oceanic Sciences, vol. 17, no. 4, pp. 883-902, 2006.

[31] Z. Lin, X. Sun, H. Strauss et al., "Multiple sulfur isotopic evidence for the origin of elemental sulfur in an iron-dominated gas hydrate-bearing sedimentary environment," Marine Geology, vol. 403, pp. 271-284, 2018.

[32] Y. Kato, K. Fujinaga, K. Nakamura et al., "Deep-sea mud in the Pacific Ocean as a potential resource for rare-earth elements," Nature Geoscience, vol. 4, pp. 535-539, 2011.

[33] D. Aubert, P. Stille, and A. Probst, "REE fractionation during granite weathering and removal by waters and suspended loads: Sr and Nd isotopic evidence," Geochimica et Cosmochimica Acta, vol. 65, pp. 387-406, 2001.

[34] M. Ayres and N. Harris, "REE fractionation and Nd-isotope disequilibrium during crustal anatexis: constraints from Himalayan leucogranites," Chemical Geology, vol. 139, pp. 249-269, 1997.

[35] M. Cathelineau, "U-TH-REE mobility during albitization and quartz dissolution in granitoids-evidence from southeast French Massif-Central," Bulletin de Mineralogie, vol. 110, pp. 249-259, 1987.

[36] L. F. Fan, S. Lin, C. W. Hsu, Y. T. Tseng, T. F. Yang, and K. M. Huang, "Formation and preservation of authigenic pyrite in the methane dominated environment," Deep Sea Research Part I: Oceanographic Research Papers, vol. 138, pp. 60-71, 2018.

[37] H. Elderfield, R. Upstill-Goddard, and E. R. Sholkovitz, "The rare earth elements in rivers, estuaries, and coastal seas and their significance to the composition of ocean waters," Geochimica et Cosmochimica Acta, vol. 54, no. 4, pp. 971-991, 1990.

[38] A. Pol, T. R. Barends, A. Dietl et al., "Rare earth metals are essential for methanotrophic life in volcanic mudpots," Environmental Microbiology, vol. 16, pp. 255-264, 2014.

[39] J. T. Keltjens, A. Pol, J. Reimann, and H. J. den Camp, "PQQdependent methanol dehydrogenases: rare-earth elements make a difference," Applied Microbiology and Biotechnology, vol. 98, pp. 6163-6183, 2014.

[40] A. M. Shiller, E. W. Chan, D. J. Joung, M. C. Redmond, and J. D. Kessler, "Light rare earth element depletion during _Deepwater Horizon_ blowout methanotrophy," Entific Reports, vol. 7, no. 1, p. 10389, 2017.

[41] G. Bayon, D. Birot, L. Ruffine et al., "Evidence for intense REE scavenging at cold seeps from the Niger Delta margin," Earth and Planetary Science Letters, vol. 312, pp. 443-452, 2011.

[42] S. Otosaka and S. Noriki, "REEs and Mn/Al ratio of settling particles: horizontal transport of particulate material in the northern Japan trench," Marine Chemistry, vol. 72, pp. 329$342,2000$.

[43] B. Zhang, M. Pan, D. Wu, and N. Wu, "Distribution and isotopic composition of foraminifera at cold-seep site 973-4 in the Dongsha area, northeastern South China Sea," Journal of Asian Earth Sciences, vol. 168, pp. 145-154, 2018.

[44] J. Feng, S. Yang, H. Wang, J. Liang, Y. Fang, and M. Luo, "Methane source and turnover in the shallow sediments to the west of Haima cold seeps on the northwestern slope of the South China Sea," Geofluids, vol. 2019, 18 pages, 2019.
[45] S. K. Hsu, C. W. Chiang, R. L. Evans et al., "Marine controlled source electromagnetic method used for the gas hydrate investigation in the offshore area of SW Taiwan," Journal of Asian Earth Sciences, vol. 92, pp. 224-232, 2014.

[46] X. Wang, T. S. Collett, M. W. Lee, S. Yang, Y. Guo, and S. Wu, "Geological controls on the occurrence of gas hydrate from core, downhole log, and seismic data in the Shenhu area, South China Sea," Marine Geology, vol. 357, pp. 272-292, 2014.

[47] W. Zhang, J. Liang, J.'. Lu et al., “Accumulation features and mechanisms of high saturation natural gas hydrate in Shenhu area, northern South China Sea," Petroleum Exploration and Development, vol. 44, no. 5, pp. 708-719, 2017.

[48] P. C. Chuang, T. F. Yang, W. L. Hong et al., "Estimation of methane flux offshore SW Taiwan and the influence of tectonics on gas hydrate accumulation," Geofluids, vol. 10, 510 pages, 2010.

[49] S. Conti, A. Artoni, and G. Piola, "Seep-carbonates in a thrustrelated anticline at the leading edge of an orogenic wedge: the case of the middlethrust-related anticline at ridge (northern Apennines, Italy)," Sedimentary Geology, vol. 199, pp. 233$251,2007$.

[50] C. Berndt, W. C. Chi, M. Jegen et al., "Tectonic controls on gas hydrate distribution off SW Taiwan," Journal of Geophysical Research: Solid Earth, vol. 124, pp. 1164-1184, 2019.

[51] D. S. Alibo and Y. Nozaki, "Dissolved rare earth elements in the South China Sea: geochemical characterization of the water masses," Journal of Geophysical Research-Oceans, vol. 105, pp. 28771-28783, 2000.

[52] K. A. De Jong, "Tectonics of the Persian Gulf, Gulf of Oman, and southern Pakistan region," in The Ocean Basins and Margins, pp. 315-351, Springer, 1982.

[53] T. Akagi, F. F. Fu, Y. Hongo, and K. Takahashi, "Composition of rare earth elements in settling particles collected in the highly productive North Pacific Ocean and Bering Sea: implications for siliceous-matter dissolution kinetics and formation of two REE-enriched phases," Geochimica et Cosmochimica Acta, vol. 75, pp. 4857-4876, 2011.

[54] D. Feng, D. Chen, J. Peckmann, and G. Bohrmann, “Authigenic carbonates from methane seeps of the northern Congo fan: microbial formation mechanism," Marine and Petroleum Geology, vol. 27, pp. 748-756, 2010.

[55] J. Wei, Y. Fang, H. Lu et al., "Distribution and characteristics of natural gas hydrates in the Shenhu Sea area, South China Sea," Marine and Petroleum Geology, vol. 98, pp. 622-628, 2018.

[56] L. Chen, M. Jin, X. Wang, H. Wang, and N. Li, "The effects of diagenetic processes and fluid migration on rare earth element and organic matter distribution in seep-related sediments: a case study from the South China Sea," Journal of Asian Earth Sciences, vol. 191, article 104233, 2020.

[57] J. N. Pattan, C. M. Rao, N. C. Higgs, S. Colley, and G. Parthiban, "Distribution of major, trace and rare-earth elements in surface sediments of the Wharton basin, IndianOcean," Chemical Geology, vol. 121, pp. 201-215, 1995.

[58] B. Huang, H. Tian, X. Li, Z. Wang, and X. Xiao, "Geochemistry, origin and accumulation of natural gases in the deepwater area of the Qiongdongnan Basin, South China Sea," Marine and Petroleum Geology, vol. 72, pp. 254-267, 2016.

[59] S. Liu, Z. Lai, Y. Wang et al., "Growing pattern of mega-dunes in the Badain Jaran Desert in China revealed by luminescence ages," Quaternary International, vol. 410, pp. 111-118, 2016. 
[60] S. Wan, D. Feng, F. Chen, C. Zhuang, and D. Chen, "Foraminifera from gas hydrate-bearing sediments of the northeastern South China Sea: proxy evaluation and application for methane release activity," Journal of Asian Earth Sciences, vol. 168, pp. 125-136, 2018.

[61] D. Feng, D. Chen, and J. Peckmann, "Rare earth elements in seep carbonates as tracers of variable redox conditions at ancient hydrocarbon seeps," Terra Nova, vol. 21, pp. 49-56, 2009.

[62] H. Cao, Z. Sun, N. Wu et al., "Mineralogical and geochemical records of seafloor cold seepage history in the northern Okinawa trough, East China Sea," Deep Sea Research Part I: Oceanographic Research Papers, vol. 155, article 103165, 2020.

[63] B. A. Haley, G. P. Klinkhammer, and J. McManus, "Rare earth elements in pore waters of marine sediments," Geochimica et Cosmochimica Acta, vol. 68, no. 6, pp. 1265-1279, 2004.

[64] S. M. de Beukelaer, I. R. MacDonald, N. L. Guinnasso Jr., and J. A. Murray, "Distinct side-scan sonar, RADARSAT SAR, and acoustic profiler signatures of gas and oil seeps on the Gulf of Mexico slope," Geo-Marine Letters, vol. 23, no. 3-4, pp. 177186, 2003.

[65] C. R. German and H. Elderfield, "Rare earth elements in Saanich Inlet, British Columbia, a seasonally anoxic basin," Geochimica et Cosmochimica Acta, vol. 53, no. 10, pp. 2561-2571, 1989.

[66] C. J. Bertram and H. Elderfield, "The geochemical balance of the rare earth elements and neodymium isotopes in the oceans," Geochimica et Cosmochimica Acta, vol. 57, no. 9, pp. 1957-1986, 1993.

[67] E. R. Sholkovitz, W. M. Landing, and B. L. Lewis, "Ocean particle chemistry: the fractionation of rare earth elements between suspended particles and seawater," Geochimica et Cosmochimica Acta, vol. 58, no. 6, pp. 1567-1579, 1994.

[68] J. Liao, X. Sun, D. Li et al., "New insights into nanostructure and geochemistry of bioapatite in ree-rich deep-sea sediments: la-icp-ms, tem, and z-contrast imaging studies," Chemical Geology, vol. 512, pp. 58-68, 2019.

[69] Y. Wang, J. Sun, H. Chen, F. Guo, L. Wang, and J. Zhang, "Study on the occurrence state of rare earth elements in soil," Nuclear and Radiochemistry, vol. 18, no. 3, pp. 146-146, 1996.

[70] P. A. Allison, S. P. Hesselbo, and C. E. Brett, "Methane seeps on an early Jurassic dysoxic seafloor," Palaeogeography, Palaeoclimatology, Palaeoecology, vol. 270, pp. 230-238, 2008.

[71] F. J. González, L. Somoza, R. Lunar et al., "Hydrocarbonderived ferromanganese nodules in carbonate-mud mounds from the Gulf of Cadiz: mud-breccia sediments and clasts as nucleation sites," Marine Geology, vol. 261, pp. 64-81, 2009.

[72] J. Wei, T. Wu, X. Deng, Z. Yu, and L. Wang, "Acoustic characteristics of cold-seep methane bubble behavior in the water column and its potential environmental impact," Acta Oceanologica Sinica, vol. 39, no. 5, pp. 133-144, 2020. 